\title{
CONFERÊNCIA \\ RESTRIÇÕES E LIBERDADES TEXTUAIS, INSERÇÃO SOCIAL E CIDADANIA
}

Jean-Paul Bronckart*

\section{Apresentação ${ }^{1}$}

econhecido internacionalmente como um dos grandes pen
sadores que se voltam para o estudo das relações entre a linguagem e o desenvolvimento humano, filiado à tradição teórica de Spinoza, Marx e Vygotsky, Jean-Paul Bronckart assume um posicionamento epistemológico e político, que, dentre outras teses, defende o papel central que a linguagem desempenha no agir humano, em seu funcionamento psíquico e em seu desenvolvimento, o que o levou, desde muito cedo, a buscar uma formação intensiva na área da Lingüística, caracterizando-se o conjunto de seus trabalhos por uma abordagem transdisciplinar das relaçōes entre a linguagem, o agir e o desenvolvimento. Desde 1980 até o final da década

* Universidade de Genebra - UNIGE.

1 Esta conferência foi proferida pelo Prof. Dr. Jean-Paul Bronckart, durante a realização do $14^{\circ}$. INPLA, congresso promovido pelo Programa de Estudos Pós-graduados em Lingüística Aplicada e Estudos da Linguagem, da Pontifícia Universidade de São Paulo, no qual o Prof. Bronckart atuou como palestrante da sessão inaugural e como debatedor do simpósio "Painel de pesquisas brasileiras e portuguesas no quadro do interacionismo sóciodiscursivo: aportes teóricos e metodológicos e novas tendências", coordenado pela Prof ${ }^{\mathrm{a}}$. Dr ${ }^{\mathrm{a}}$. Anna Rachel Machado (PUC/SP) e pelo Prof. Dr. Rosalvo Pinto (UFMG). A apresentação foi feita por Anna Rachel Machado, responsável também pela tradução da conferência, que teve Adail Sobral como seu revisor. 
de 90, como coordenador de um grupo de pesquisadores da Unidade de Didática das Línguas, da Universidade de Genebra, do qual faziam parte os professores Daniel Bain, Bernard Schneuwly, Joaquim Dolz, Itziar Plazaola e muitos outros, participou de inúmeros trabalhos de pesquisa, que podem ser agrupados em cinco grandes tipos:

1. Os que visavam a constituir um modelo coerente da estrutura e do funcionamento dos textos/discursos do francês contemporâneo, cujos resultados foram divulgados no livro "Le fonctionnement des discours” (Bronckart et al., 1985), e posteriormente aplicado a textos produzidos em outras línguas, como o alemão, o basco, o italiano e o português. Esse modelo sofreu uma substancial formulação, que foi exposta no livro "Activité langagière, textes et discours" (Bronckart, 1997), traduzido por Anna Rachel Machado para o português em 1999.

2. Os que incidiam sobre a aprendizagem de elementos centrais da organização textual (como por exemplo, a utilização dos tempos verbais, dos organizadores textuais, dos procedimentos de modalização etc.), por crianças ou alunos entre oito e treze anos, falantes de diferentes línguas.

3. Os trabalhos em didática de línguas visando à reforma dos programas de ensino de linguas da Suiça francofone, à elaboração de livros didáticos e de seqüências didáticas.

4. Os de natureza mais teórica tratando da epistemologia das ciências humanas e das conseqüências a serem tiradas da teoria saussureana do signo e das teorias da ação.

5. Os que incidem sobre a análise das ações e dos discursos em situação de trabalho, desenvolvido por um subgrupo de pesquisa constituído em 2001 (Grupo LAF - Langage-Action-Formation), ainda coordenado pelo Prof. Bronckart, e que conta com colaboradores internacionais, destacando-se dentre eles o Prof. Dr. Yves Clot (CNAM/Paris), o Prof. Dr. Daniel Faïta (IUFM- Marselha) e a Prof ${ }^{a}$ $D^{\mathrm{a}}$. Anna Rachel Machado (LAEL - PUC/SP). 
Rev. ANPOLL, n 19, p. 231-256, jul./dez. 2005.

Pelo exposto, é fâcil compreender as razões pelas quais pesquisadores brasileiros voltados para as questōes de ensino-aprendizagem de produção e leitura de textos e, mais recentemente, para a compreensão do trabalho educacional, da área da Lingüística e da Lingüística Aplicada, principalmente os que aderem à linha vygotskyana, logo se interessassem pelos trabalhos do grupo de Genebra, assim que estes foram sendo conhecidos. Esse interesse se concretizou em 1994, com o estabelecimento de um Acordo Interinstitucional entre o LAEL (PUC/SP) e a Unidade de Didática de Linguas da Universidade de Genebra. A partir desse núcleo inicial, a discussão das idéias do interacionismo sociodiscursivo tem-se expandido no Brasil, de forma evidente, nesses últimos dez anos. Assim, a publicação desta conferência neste número da revista da ANPOLL parece-nos ser bastante relevante para a difusão do desenvolvimento das idéias mais atuais do Prof. Bronckart para nossa comunidade científica.

Restrições e liberdades textuais, inserção social e cidadania

O título desta conferência me foi proposto por Anna Rachel Machado. Como ela conhece perfeitamente bem os nossos trabalhos, esse tema também me convém perfeitamente. Em primeiro lugar, abordarei mais detidamente:

- de um lado, a problemática da articulação entre coerções ou restrições textuais e, de outro, a problemática da criatividade e da liberdade textual;

- a seguir, como a abordagem dessa articulação inscreve-se na perspectiva mais ampla das relações entre determinismo social e criatividade individual, abordarei alguns aspectos do papel da atividade de linguagem no desenvolvimento dos processos de inserção social e de construção da cidadania.

O tratamento que darei a essas duas questões inscreve-se no quadro teórico e metodológico do interacionismo sociodiscursivo, 
teoria que venho desenvolvendo, há vinte anos, ao lado de vários colaboradores de Genebra e de alguns colegas de outros países e da qual destacarei, como introdução a esta conferência, cinco principios gerais. Os quatro primeiros são comuns ao movimento interacionista em geral e o quinto é específico à nossa abordagem, princípio este que justifica o acréscimo de "discursivo" ao adjetivo "social" (daí advindo o adjetivo "sociodiscursivo"). Esses principios são os seguintes:

(a) Considerar, contra o positivismo e o fracionamento das disciplinas que ele gerou nas ciências humanas/sociais, que elas têm um só e único objeto, que pode ser definido como sendo tudo aquilo que se refere às condições de desenvolvimento e funcionamento das condutas humanas. Conseqüentemente, nosso trabalho visa a contribuir para a reorganização dessas disciplinas no quadro de uma "ciência do espírito e das obras" e é mais ou menos inspirado diretamente pelo projeto e pelo programa de Dilthey (1883/1992): precisamos ser, ao mesmo sociólogo, lingüista, psicólogo, formador etc.

(b) Considerar, contra todas as formas de idealismo e de subjetivismo, que o primeiro elemento que devemos considerar para tratar desse objeto é a sócio-história humana. Qualquer novo fato social, lingüístico, psicológico etc. é construído tendo como pano de fundo as práticas, os conhecimentos e os valores que já nos são dados, oriundos das gerações anteriores e que são portadores das significações que essas gerações construiram. Em outros termos, qualquer processo de desenvolvimento realiza-se tendo como pano de fundo os pré-construtos humanos, que abordarei mais em detalhes mais à frente.

(c) O desenvolvimento humano se efetiva no agir, o que significa, em primeiro lugar, que todos os conhecimentos construídos são produtos de um agir e não de secreções diretas do cérebro, do espírito ou da alma. Emprego aqui o termo "agir", que não é familiar, para indicar que hà, em relação a esse domínio, séri- 
Rev. ANPOLL, nº 19, p. 231-256, jul./dez. 2005.

os problemas teóricos, principalmente no que se refere à distinção entre "atividade", "ação", "prática” etc. Em segundo lugar, assumir que o desenvolvimento humano efetiva-se no agir também implica um posicionamento de ordem epistemológica e política: o de que os conhecimentos científicos que focalizam o humano também devem ser construídos em trabalhos de intervenção ou, em outras palavras, como Durkheim (1894-95/1963) já sustentava firmemente há um século e como Touraine o faz mais recentemente (1973), implica considerar que as ciências humanas/sociais devem se dotar de meios para serem úteis, para contribuírem para uma evolução positiva dos grupos sociais e de seus membros.

(d) De acordo com as formulações de Mead (1934), os processos de socialização (de construção dos fatos sociais) e os processos de individualização (isto ê, de formação das pessoas individuais) são duas vertentes complementares e indissociáveis do mesmo desenvolvimento humano. Isso significa assumir que os processos que contribuem para as mudanças das instituições, das normas e das representações coletivas são os mesmos que contribuem para a transformação das condições em que as pessoas agem.

(e) A linguagem desempenha um papel decisivo, fundamental ou sine qua non no desenvolvimento. De um lado, ela contribui de modo extremamente significativo para codificar os pré-construtos históricos (construindo a "memória" desses pré-construtos, como afirma Bakhtin - 1984). De outro, ela organiza, comenta, regula as ações e as interações humanas, no quadro das quais se re-produzem ou se re-constroem os fatos sociais e psicológicos. Esse papel da linguagem não decorre de sua dimensão de sistema, de código, mas sim do fato de que ela é, antes de tudo, uma atividade, uma prática, ou ainda, de que ela é da ordem do que habitualmente se chama de discurso.

Estabelecidos esses principios, abordarei a seguir os temas desta conferência em cinco etapas: 
(1) Um breve exame dos pré-construtos sócio-histôricos humanos em geral, dentre os quais destacarei os pré-construtos linguageiros ou textuais.

(2) Um exame mais técnico dos niveis de manifestação das coerções ou das restrições relacionadas à textualidade: dos gêneros de textos, dos signos, dos tipos de discurso, dos mecanismos de textualização e das relações predicativas.

(3) Um exame das condições de realização das ações de linguagem, com ênfase nas capacidades reflexivas e criativas que os agentes mostram ao realizá-las.

(4) Um exame dos processos dialéticos de mediação da linguagem, por meio dos quais os agentes, a partir de um certo nivel de maestria das coerções existentes, podem, ao mesmo tempo, desenvolver sua própria pessoa e transformar os pré-construtos linguageiros.

(5) A defesa da tese de que o domínio do funcionamento textual é um fator importante, se não decisivo, para o desenvolvimento das interações sociais e da cidadania.

\section{Uma abordagem dos pré-construtos humanos}

Em nossa abordagem geral dos prē-construtos humanos, distinguimos entre as atividades coletivas, as formações sociais, os textos e os mundos formais de conhecimento.

\subsection{As atividades coletivas}

O ambiente de qualquer organismo vivo é constituído não só pelo meio físico, mas também, e, sobretudo, pelos comportamentos de seus congêneres. Nas espécies animais socializadas, esses comportamentos apresentam-se na forma de atividades organizadas e orientadas pelas funções gerais de sobrevivência (nutrição, repro- 
Rev. ANPOLL, n 19, p. 231-256, jul./dez. 2005.

dução, fuga do perigo etc.). Quanto ao homem, essas atividades coletivas liberaram-se das exigências imediatas da sobrevivência e tornaram-se tão complexas que se constituíram como quadros que organizam e, portanto, servem para mediar tudo aquilo que é essencial nas relações entre os organismos particulares e o meio fisico (cf. Leontiev, 1979): portanto, essas atividades devem ser consideradas como o elemento primeiro ou o elemento fundamental do meio humano.

Ressaltemos ainda que essas atividades exploram instrumentos ou ferramentas e propiciam a produção de objetos sociais e de obras culturais, que se tornam, por sua vez, elementos do meio humano geral. Observe-se também que essas atividades, desde seu início, já eram muito diferentes, diversidade essa que se apresenta como resultado das diferenças entre os meios de vida e do fato de que os grupos humanos foram historicamente estruturados por meio de regras convencionais variáveis.

\subsection{As formaçōes sociais}

As formações sociais ou "classes" sociais, pelo menos em parte, são resultado do processo de diversificação que acabamos de mencionar. Elas podem ser definidas como sendo as formas concretas que tomam as organizações da atividade humana ou, de modo mais geral, da vida humana, em função dos diferentes contextos físicos, econômicos e históricos. Essas formações geram representações, normas, valores etc. que se relacionam às diferentes modalidades de regulação das interações entre membros de um mesmo grupo e que, devido à "divisão do trabalho" e aos jogos de poder que ela desencadeia, são sempre potencialmente conflitantes.

\subsection{Os textos}

O desenvolvimento histórico da atividade coletiva humana é indissociável da emergência da linguagem verbal. Consideramos que 
essa linguagem constitui-se, em primeiro lugar, como uma atividade, mas uma atividade particular, cuja função primordial é a de significar, de construir sentido (cf. Coseriu, 2001), e que, em razão mesmo desse estatuto, apresenta duas funções secundárias: a de regular a atividade em geral (ou atividade não linguageira) e a de representar (declarativamente) os conhecimentos. Explorando o material ou os recursos de uma determinada língua natural, a atividade de linguagem apresenta-se na forma de textos, cujas caracteristicas funcionais e estruturais serão abordadas mais adiante.

\subsection{Os mundos formais de conhecimento}

Por sua própria função declarativa, a atividade de linguagem gera representações coletivas, que podem distanciar-se das coerções específicas da textualidade, descontextualizarem-se, generalizarem-se e organizarem-se em outros regimes lógicos ou no que alguns autores denominam de mundos representados ou mundos formais (cf. Habermas, 1987). De acordo com as proposições desse autor, distinguimos três tipos de mundos formais: o mundo objetivo reúne e organiza as representações do meio no seu aspecto físico (ou causal), o mundo social reúne e organiza as representações referentes às modalidades de realização das atividades humanas, que são necessariamente convencionais e históricas e, finalmente, o mundo subjetivo reúne e organiza as representações referentes às modalidades de auto-apresentação das pessoas nas interações (ou a "imagem" que as pessoas dão de si mesmas).

\section{Desenvolvimento sobre o estatuto dos textos}

Como dissemos, a atividade de linguagem apresenta-se empiricamente na forma de textos (orais ou escritos) que se constroem com a mobilização dos recursos lexicais e sintáticos de uma 
Rev. ANPOLL, n 19 , p. 231-256, jul./dez. 2005.

determinada língua natural. Assim, os textos podem ser definidos como sendo os correspondentes empíricos/lingüísticos das atividades de linguagem de um grupo. Desse ângulo e de modo paradoxal, embora o texto mobilize unidades lingüísticas, ele não é, em si mesmo, uma unidade lingüistica: suas condições de abertura, de fechamento (e, provavelmente, de planificação geral) não dependem do estritamente lingüistico, mas são determinadas pela atividade que o gera. E é por isso que consideramos o texto como sendo uma unidade comunicativa.

Além disso, existem classes diferentes de textos, devido ao fato de que eles comentam atividades humanas cuja variedade é ilimitada e ao fato de que esses comentários realizam-se no quadro de situações de interação comunicativa que também são infinitamente variadas. Além disso, como as atividades humanas e as situações de interação modificam-se no decorrer da história social, a configuração das classes de texto também se modifica no decorrer da história.

Se, no plano ontológico, podemos contentar-nos com essa evidência da diversidade e da transformação dos textos; no plano gnoseológico, defrontamo-nos com o problema de sua descrição, classificação e nomeação em gêneros (romance, novela, editorial, receita, reportagem, conversação etc.). Esse problema é particularmente revelador, já que tem sido abordado desde a Antigüidade grega, sendo discutido pelos melhores "sábios", e já que, mesmo assim, continua até hoje sem uma solução adequada. A causa fundamental dessa impotência está no fato de que os gêneros de textos não podem nunca ser identificados e definidos com base em suas propriedades lingüisticas e que, portanto, qualquer classificação feita com base na correspondência entre propriedades do contexto e propriedades do texto é impossivel.

Por outro lado, pelo fato de que os textos são praticados e avaliados, eles são marcados por indices de valor sociais: - um indice de valor referencial (qual é o tipo de atividade que o texto é ade- 
quado para comentar?) - um indice de valor comunicacional (qual é o tipo de interação social no quadro da qual se efetua esse comentário?); - um indice de valor cultural (qual é o "valor socialmente adicionado" a um gênero, enquanto efeito dos mecanismos e dos jogos de poder que organizam os "campos de produção"? (cf. Bourdieu, 1980). Entretanto, mesmo que a identificação e a classificação dos gêneros continuem sendo sempre problemáticas, o fato é que os gêneros de textos existem, ou melhor, co-existem no ambiente linguageiro e que se acumulam historicamente em um sub-espaço dos préconstrutos humanos, que denominamos, retomando essa noção, o arquitexto de uma determinada comunidade verbal.

\subsection{As coerções da textualidade}

Tal como os analisamos aqui, as classes ou gêneros de textos preexistentes no arquitexto constituem-se como modelos dotados de uma determinada indexação social, isto é, são considerados como pertinentes e adaptados a um determinado conteúdo temático e a uma determinada situação de interação. Essa indexação constituise como um primeiro nivel de coerção.

Mas há outros niveis de coerções que se relacionam ao fato de que, se todo texto materializa uma atividade de linguagem, essa materialização realiza-se com a mobilização dos recursos de uma lingua natural, que são diversos, mas limitados. Portanto, essas limitações também condicionam os niveis de estruturação infraordenados dos textos.

No nivel lexical, os signos são constituídos com significantes, cuja composição sonora é extremamente variável, pois a relação desses significantes com as entidades que representam é imotivada ou independente das propriedades "naturais" dessas entidades. Mas os signos também se caracterizam, sobretudo, por sua arbitrariedade radical: são formas coletivas aleatórias que têm a capacidade de reorganizar (ou de reanalisar) as imagens mentais idiossincráticas 
Rev. ANPOLL, no 19, p. 231-256, jul./dez. 2005.

dos indivíduos, permitindo assim que elas sejam compartilháveis ou comunicáveis. Tomemos o exemplo da problemática das cores. No plano físico, esse fenômeno apresenta-se na forma de um continuum de comprimento de ondas perceptiveis pelo olho humano. Em um segundo plano, no psicológico, podem ser apreendidas diversas imagens mentais que um ser humano é teoricamente capaz de construir em relação a esse fenômeno físico. Enfim, em um terceiro plano, o lingüístico, podem ser identificados os diversos significantes de que uma lingua natural dispõe para se referir a esse fenômeno e podem ser identificados, ao mesmo tempo, os seus significados correspondentes, que são, obrigatoriamente, reagrupamentos ou reanálises das múltiplas imagens mentais possíveis. Na medida em que, para todo o universo de referência, cada língua natural dispõe de um paradigma de significantes cujo número de itens e de organização interna pode variar muito, nossa capacidade de "dizer" esses universos encontra-se submetida a restrições determinadas pelas características específicas dos paradigmas disponiveis na lingua que utilizamos. Além disso, as estruturas morfossintáticas também são formas convencionais que traduzem e organizam de forma arbitrária as operações de combinação dos signos mínimos.

Em nossa abordagem dessas estruturas, distinguimos primeiramente os tipos de discurso, definidos como configurações particulares de unidades e de estruturas lingüisticas, em número limitado, que podem ser componentes de qualquer texto. O conteúdo semiotizado pode ser explicitamente distanciado das coordenadas da situação de ação do agente (ordem do NARRAR) ou não (ordem do EXPOR); além disso, as instâncias de agentividade semiotizadas podem estar relacionadas com o agente e com sua situação de ação (implicação) ou não (autonomia). O cruzamento do resultado dessas decisões produz quatro mundos discursivos (NARRAR implicado, NARRAR autônomo, EXPOR implicado, EXPOR autônomo), que são expressos (ou exprimiveis) por quatro tipos lingüisticos (relato interativo, narração, discurso interativo, discurso teórico). 
Esses tipos encontram-se presentes nas diferentes linguas, mas as unidades e a estrutura que os marcam variam de lingua para língua, como nos mostram estudos comparativos desenvolvidos, por exemplo, sobre o alemão, o basco, o catalão, o castelhano, o italiano e o português, em comparação com nossos estudos feitos sobre o francês. Desse modo, podemos dizer que cada lingua formata, de um modo próprio, os mundos de interação discursiva.

A seguir, distinguimos os mecanismos de textualização, que contribuem para dar coerência ou unidade ao texto, apesar da heterogeneidade derivada da ocorrência dos diferentes tipos de discurso que podem compô-lo: de um lado, temos os mecanismos que garantem a coerência linear e temática, por meio dos processos isotópicos de conexão, de coesão nominal (de retomada anafórica) e de coesão verbal; de outro, os mecanismos que garantem a coerência enunciativa ou interativa, por meio do jogo da distribuição das vozes e das modalizações.

O determinismo das linguas, nesse nivel, parece ser mais importante do que o dos tipos de discurso. De fato, embora todas as linguas devam, necessariamente, fornecer os meios para serem realizadas essas operações mais gerais, que são as operações de conexão, de coesão, de distribuição de vozes e de modalização, elas utilizam procedimentos diferentes para isso, sob o efeito dos quais algumas sub-operações podem, ou não, ser objeto do que atualmente se chama de gramaticalização: por exemplo, existem em algumas linguas, e não em outras, estruturas de diátese ${ }^{2}$, de apassivação ou de mediação, o que gera, necessariamente, diferenças na própria natureza das sub-operações que um agente deve desenvolver para elaborar um texto.

Enfim, distinguimos ainda as estruturas predicativas ou oracionais. Elas podem se organizar em um sistema acusativo ou

2 Nota da tradutora: estruturas de diátese são estruturas referentes aos papéis semânticos dos actantes. 
Rev. ANPOLL, no 19, p. 231-256, jul./dez. 2005.

em um sistema ergativo, sem que possamos identificar qualquer motivação de ordem natural para a adoção de um ou de outro desses sistemas. Além disso, dentro de um mesmo sistema lingüîstico, há uma quase infinita diversidade das relações lógico-semânticas que podem ser estabelecidas entre dois termos (por exemplo, as relações que as seguintes orações exprimem: "Pierre é grande", "Esse livro é de Pierre" "Pierre atravessou a praça", "Pierre dorme", Pierre encontrou Maria"), relações essas que devem necessariamente ser moldadas em uma das formas de estruturas predicativas de que a lingua dispõe. Como em relação ao léxico, esse enquadramento das operações cognitivas nas estruturas oracionais da língua apresenta um caráter aleatório ou radicalmente arbitrário e, portanto, impõe uma coerção real sobre as modalidades de expressão das relações lógicas.

Portanto, assim como os modelos de gêneros indexados, também as configurações de signos, os tipos de discurso, os mecanismos de textualização e as estruturas predicativas são elementos de coerção ou restrição. Mas, para compreender como essas coerções operam efetivamente, é necessário analisar a situação na qual todo produtor de um novo texto se encontra, isto é, as condições de realização de uma (nova) ação de linguagem.

\section{As condições de realização das ações de linguagem}

As ações de linguagem novas desenvolvem-se em um determinado contexto de produção e exprimem ou semiotizam um determinado conteúdo referencial.

O contexto de produção pode ser definido como o conjunto dos parâmetros que podem exercer influência sobre o modo como um texto é organizado. Embora, teoricamente, múltiplos aspectos de uma situação de ação possam ser considerados (as condições climáticas, a refeição que o produtor fez, seu estado emocional etc.), 
de acordo com a maioria dos estudiosos da questão, consideramos aqui os únicos fatores que exercem uma influência necessária (mas não mecânica!) sobre a organização dos textos. Esses fatores se agrupam em dois conjuntos: o primeiro refere-se ao mundo físico e o segundo, ao mundo social e subjetivo.

Em relação ao primeiro conjunto, podemos dizer que todo texto é resultante de um comportamento verbal concreto, desenvolvido por um agente situado nas coordenadas do espaço e do tempo; portanto, todo texto procede de um ato realizado em um contexto "físico", que pode ser definido por quatro parâmetros precisos:

- o lugar de produção: o local onde o texto é produzido;

- o momento de produção: a extensão de tempo durante a qual o texto é produzido;

- o emissor (ou produtor, ou locutor): a pessoa (ou a máquina) que produz fisicamente o texto, na modalidade oral ou na escrita;

- o receptor: a(s) pessoa(s) que pode(m) perceber (ou receber) concretamente o texto.

Em relação ao segundo conjunto, a produção de todo texto inscreve-se no quadro da atividade de uma formação social e, mais precisamente, no quadro de uma forma de interação comunicativa que implica o mundo social (normas, valores, regras etc.) e o mundo subjetivo (imagem que o produtor dá de si mesmo ao agir). Esse contexto sócio-subjetivo também pode ser decomposto em quatro parâmetros principais:

- o lugar social: no quadro de que formação social, de qual instituição ou, de forma mais geral, em que modalidade de interação o texto é produzido: escola, família, mídia, exército, comércio conversa informal etc.?

- a posição social do emissor (que lhe confere seu estatuto de enunciador): qual o papel social que o emissor desempenha na 
Rev. ANPOLL, n 19, p. 231-256, jul./dez. 2005.

interação em curso: papel de professor, de pai, de cliente, de superior hierárquico, de amigo etc.?

- a posição social do receptor (que lhe confere seu estatuto de destinatário): qual o papel atribuído ao receptor do texto: papel de aluno, de criança, de colega, de subordinado, de amigo etc. ?

- o(s) objetivo(s) da interação: qual é (são), do ponto de vista do enunciador, o(s) efeito(s) que o texto é capaz de produzir no destinatário?

O conteúdo referencial é constituído pelos conhecimentos disponiveis na memória dos agentes, organizados em macroestruturas semânticas. Tanto o contexto de produção quanto o conteúdo referencial são representações disponiveis no agente e são uma base de orientação ou base de partida, a partir da qual ele vai, primeiro, adotar um modelo de gênero que lhe pareça ser pertinente e eficaz em sua situação, com todas as características estruturais coercitivas desse gênero (signos, tipos de discurso, mecanismos de textualização etc.).

Mas o agente vai também, quase que necessariamente, adaptar o modelo escolhido. Ele pode efetuar essa adaptação logo no início, ao considerar eventuais caracteristicas particulares de sua situação de produção. Mas ele também o adapta mais freqüentemente, no decorrer de sua ação de linguagem, que se realiza em uma determinada duração temporal, durante a qual o agente pode encontrar problemas, dificuldades etc. É então que ele vai mobilizar suas capacidades de reflexividade - evidenciadas principalmente pela etnometodologia e por todas as correntes da sociologia descendente, desde a obra de Simmel - para modificar determinados aspectos de sua produção textual. E é nesse jogo entre adoção e adaptação que se realizam as mediações linguageiras que são potencialmente capazes de desenvolver as pessoas e o social. 


\section{Os processos de mediação de linguagem 4.1. Os quatro espaços de mediação}

Em primeiro lugar, como vimos, na produção de um novo texto, o agente escolhe um modelo de gênero, mas ele dispõe de uma significativa margem de liberdade, principalmente em relação à planificação geral do conteúdo temático e em relação às modalidades de articulação dos tipos de discurso possiveis. Ele vai, portanto, introduzir variantes em relação a esse modelo, decorrentes de uma estilística pessoal ou social. No curso desse primeiro processo, o da mediação pelos gêneros, o agente, de um lado, desenvolve seu conhecimento sobre os gêneros que são adaptados a uma situação de interação, com o conjunto das coerções lingüísticas que lhes são prôprias, e de outro, também aprende a dominar as indexações sociais que cada gênero traz em si. Assim, o agente insere-se nas redes de significações cristalizadas nos modelos preexistentes e aprende a situar-se em relação a elas. Esse é o aspecto de desenvolvimento pessoal dessa mediação. Além disso, as variantes produzidas constituem-se como candidatas a uma restituição ao arquitexto e, assim, podem produzir uma modificação mais ou menos significativa das características anteriores dos gêneros. Esse é o aspecto de desenvolvimento social dessa mediação.

Em segundo lugar, quando o agente (re)-produz os signos mobilizados em um texto, ele deve necessariamente tomá-los dos paradigmas de palavras que, de acordo com o "consentimento" subjacente ao uso de uma língua natural, podem "traduzir" aspectos mais ou menos delimitados de um determinado domínio de referência. Na maioria dos casos, esses paradigmas são complexos e contêm vários signos que podem ser aplicados a um mesmo referente e que, portanto, encontram-se em uma situação objetiva de concorrência. A decisão de mobilizar um dos signos de um paradigma em vez de outro é muito condicionada pelas escolhas efetuadas no nivel dos gêneros de textos e inscreve-se em um processo de media- 
Rev. ANPOLL, n 19, p. 231-256, jul./dez. 2005.

ção pelos signos, que é da mesma ordem: ao escolher os signos, o agente apropria-se progressivamente das nuances semânticas de que eles são portadores em um determinado estado da lingua (vertente do desenvolvimento pessoal), mas, ao mesmo tempo, há também a possibilidade de o agente deslocar a relação de significação, em geral levemente, e, desse modo, contribuir para a evolução diacrônica dos paradigmas e dos campos semânticos da língua usada (vertente do desenvolvimento social).

Em terceiro lugar, quando o agente (re-) produz um tipo de discurso, ele aprende a mobilizar os recursos lingüisticos que lhe são apropriados e a dominar suas relações de interdependência. Mas, além dessa aprendizagem técnico-lingüistica, ele também aprende a inserir-se nas coordenadas formais dos mundos discursivos que os tipos de discurso exprimem e, ao fazer a planificação interna dos segmentos envolvidos (organizando as seqüencialidades), ele também aprende a utilizar, organizadamente, os processos indissoluvelmente mentais e linguageiros que são os raciocinios: os raciocinios práticos implicados nas interações dialogais (cf. Roulet et al., 1985), os raciocínios causais-cronológicos implicados nos relatos e nas narrações (cf. Ricœur, 1983), os raciocínios de ordem lógica e/ ou semilógica implicados nos discursos teóricos (cf. Grize, 1984). Parece-nos que essa mediação pelos tipos apresenta um caráter mais coercitivo que a mediação pelos gêneros ou pelos signos, dado que a margem de adaptação dos agentes é muito limitada pelas propriedades do sistema da língua e/ou pelas representações que ele têm dela. Entretanto, essa mediação se constitui como um processo de desenvolvimento fundamental, na medida em que é por meio dela que se transmitem as grandes formas de operacionalidade do pensamento humano.

Finalmente, em quarto lugar, em relação aos mecanismos de textualização, damos um lugar de destaque aos mecanismos de coesão verbal, que asseguram a organização temporal e/ou hierárquica dos processos (estados, acontecimentos ou ações) verbalizados no 
texto e que são essencialmente estabelecidos pelos tempos verbais; e aos mecanismos de distribuição das vozes e de modalização, que não são diretamente relacionados à progressão temática e que, portanto, apresentam pouca dependência em relação aos elementos precedentes e subseqüentes no eixo sintagmático, podendo seu estatuto ser considerado como sendo de ordem interativa (ou configuracional, para retomar um termo de Adam, 1990). A distribuição das vozes visa a "fazer perceber" as instâncias que têm a responsabilidade sobre aquilo que é expresso (dito, visto, pensado) no texto, podendo essas vozes não ser assinaladas por marcas lingüísticas especificas ou ser explicitadas por formas pronominais, sintagmas nominais, por frases ou segmentos de frases. A modalização, por sua vez, tem a função de explicitar os julgamentos ou avaliações das instâncias enunciativas sobre determinados aspectos do conteúdo semiotizado no texto ou do próprio processo de semiotização, sendo realizada por unidades ou conjuntos de unidades lingüísticas de níveis muito diferentes, que chamamos de modalidades: o futuro do pretérito, os auxiliares modalizadores, alguns advérbios, algumas frases impessoais etc. Apesar de os efeitos de mediação pela aprendizagem e pela maestria progressiva da textualização terem sido pouco estudados até o momento, eles nos parecem evidentes e importantes. Por exemplo, a aprendizagem da distribuição das vozes, em leitura e em produção, é uma boa ocasião de os alunos tomarem conhecimento das diferentes formas de posicionamento e de engajamento enunciativos construidos em um grupo, de se situarem em relação a eles, reformulando-os, processo esse que contribui para o desenvolvimento da identidade das pessoas. E, como já o mostramos em outras pesquisas, a aprendizagem e a maestria dos mecanismos de coesão verbal parecem ter efeitos decisivos em construções psicológicas altamente complexas que são as representações do tempo e de sua organização. 
Rev. ANPOLL, n 19, p. 231-256, jul./dez. 2005.

\subsection{Os diferentes processos de mediação}

Se esses processos gerais de adoção-adaptação (ou de mediação linguageira) podem operar (pelo menos) nesses quatro diferentes espaços, conforme discutido na seção anterior, eles constituem o que chamamos de trabalho ordinário ou usual sobre a língua. $\dot{E}$ um trabalho que explora as variantes possiveis dos gêneros de texto, dos tipos de discurso e dos paradigmas da língua, sem, no entanto, modificar os valores-padrão das unidades lexicais e morfossintáticas no quadro dos modelos coletivos que preexistem nesses diferentes níveis. Em outros termos, trata-se de um processo de reprodução dos possiveis "apontados" pelo estado de uma língua no momento da produção.

Entretanto, há outros procedimentos que se caracterizam por uma espécie de vontade (consciente ou inconsciente) de acentuar os aspectos de adaptação ou de transformação dos modelos preexistentes.

Por exemplo, o procedimento literário, embora se insira no processo mais geral que acabamos de discutir, parece estar baseado em uma motivação suplementar, que consiste globalmente em reconfigurar os estados, acontecimentos e/ou ações de um determinado universo de referência, transformando, ao mesmo tempo, o "olhar" que temos sobre eles ou nossa forma possivel de apreendêlos (cf. Ricoeur, 1983). Esse objetivo de transformação das representações (que sempre é, consciente ou inconscientemente, articulado a questões sociológicas, culturais ou políticas) realiza-se, quase que necessariamente, por meio de uma transformação das formas sóciolinguageiras que estruturam essas representações, isto é, por meio de transformação dos valores-padrão dos signos, presentes nos modelos preexistentes. O traballho literário sobre a língua desloca as unidades e seus valores originais, muda-os, reorganiza-os, para produzir novas formas de ver e de sentir as coisas. 
Por sua vez, o procedimento poético parece-nos ser um passo a mais no processo de adaptação ou de transformação dos modelos. Embora ele continue dependente da lógica geral dos gêneros, no sentido de que ele pode ou desenvolver-se no quadro de gêneros específicos (soneto, ode etc.) ou articular-se às regras de composição dos gêneros do cotidiano (diálogo poético, romance poético etc.), ele se caracteriza por um distanciamento e por uma liberdade maior em relação às regras-padrão da organização textual e do próprio sistema da lingua. O trabalho poético constitui-se como uma tentativa permanente de liberação das convenções lingüisticas herdadas e de sua alteridade fundamental, com a finalidade de mostrar e de fazer sentir relações, encadeamentos, processos de pensamento ou de emoção que as produções verbais usuais são, em principio, incapazes de exprimir. Ele se processa por deslocamentos constantes sobre o eixo paradigmático dos significantes e dos significados, cuja amplitude pode levar, às vezes, a se assumir uma liberdade correlativa em relação às regras de organização sintagmática. Embora a beleza desse trabalho, em parte, resulte de seu caráter desesperado (já que os signos da língua são inexoravelmente "outros" e que o projeto de uma escritura pura ou "automática" é apenas uma enésima metamorfose do fantasma idealista do paraíso perdido), ele não pára de explorar o reverso da língua e, portanto, o reverso ainda mais profundamente misterioso do funcionamento psiquico aparente.

O trabalho de formação (escolar) para a maestria da língua inscreve-se também nesse processo. Como sabemos, as crianças e os adolescentes podem, em suas produções de linguagem, demonstrar uma "criatividade" muito grande em relação aos modelos existentes, em todos os niveis da organização textual. Criatividade no deslocamento dos tempos verbais, na criação de novas palavras, de novas formas morfológicas, que, às vezes, é estreitamente análoga à de autores consagrados (como Proust, por exemplo). 
Rev. ANPOLL, n 19, p. 231-256, jul./dez. 2005.

Entretanto, essas criaçōes serão geralmente consideradas como erradas pelos formadores. Geralmente os professores têm razão nisso, porque distinguem entre uma "criatividade" que parece ser mais um resultado de uma não-maestria dos modelos existentes e uma criatividade que pressupõe essa maestria e que se apóia no conhecimento dos modelos para transformá-los em uma direção desejada.

Essa análise parece-me trazer uma implicação didática bem clara: a de que, sem dúvida, o ensino de línguas deve formar o aluno para a maestria em relação aos modelos preexistentes, mas também deve, progressivamente, e explorando a reflexividade dos alunos, desenvolver suas capacidades de deslocamento, de transformação dos modelos adquiridos. É sob essa condição que o aluno poderá desenvolver sua pessoa, ao mesmo tempo em que contribui para a transformação, isto é, para a vida da língua de seu meio.

\section{Contribuir para a integração social e para o desenvolvimento da cidadania}

A integração social e a cidadania são, respectivamente, processos e valores sociais, ou ainda, fatos sociais. Os comentários que podemos fazer sobre esse tema exigem que, em primeiro lugar, voltemo-nos para as abordagens sociológicas das condições desses fatos sociais, na perspectiva assumida no inicio dessa conferência.

Em sociologia, há correntes que chamamos de descendentes, cuja figura principal é Durkheim, que insistem nas dimensões específicas dos fatos sociais (eles não poderiam ser reduzidos à soma dos fatos individuais) e no seu caráter coercitivo: eles já estariam dados e impor-se-iam aos individuos, que, com isso, teriam uma margem de manobra muito restrita.

Entretanto, com base na obra de Simmel (1884/1981) e da Escola de Chicago desenvolveram-se outras correntes, "ascenden- 
tes", que contestam de modo mais ou menos radical a preexistência dos fatos sociais ou que, pelo menos, se colocam a questão de saber de que modo os fatos sociais são construidos. O interacionismo simbólico de Goffmann (cf. 1956/1973) e a etnometodologia (cf. Garfinkel, 1967) são as escolas mais representativas dessa corrente: consideram que a ordem social situa-se no nivel dos atores, mais precisamente no saber (prático) que demonstram e que orientam suas práticas: os membros de um grupo social e/ou cultural dispõem de métodos que lhes permitem contribuir para as atividades coletivas de modo organizado. Conseqüentemente, são essas etnometodologias que é necessário analisar. Esse saber dos membros de um grupo apresenta duas caracteristicas principais: em primeiro lugar, a reflexividade, que significa que todo ator tem a possibilidade de conhecer os procedimentos que ele mesmo desenvolve e de mostrá-los no agir ou na linguagem; em segundo lugar, a descritibilidade (accountability), pela qual os discursos que a reflexividade dos atores permite deixam ver, de modo racional e interpretável, algumas das características de suas práticas e, com isso, dão acesso ao que se constitui como a única objetividade do social.

Acreditamos que essas duas correntes não são incompativeis e que é necessário articulá-las, conceitualizar e estudar a dialética permanente que se instaura entre esses dois movimentos. E é exatamente para a busca dessa terceira via que se volta a obra do sociólogo inglês Giddens (1987). Para ele, a sociologia tem um objeto que, mesmo sendo totalmente único, caracteriza-se por sua dualidade: "as propriedades estruturais dos sistemas sociais são, ao mesmo tempo, condições e resultados das atividades desenvolvidas pelos agentes que fazem parte desses sistemas" (Giddens, 1987:15). Conseqüentemente, a "teoria da estruturação" que o autor desenvolve visa a evidenciar os processos por meio dos quais as práticas sociais procedem de propriedades estruturais já dadas e mais ou menos estáveis e recriam incessantemente essas mesmas proprie- 
Rev. ANPOLL, $n^{\circ}$ 19, p. 231-256, jul./dez. 2005.

dades, ao mesmo tempo em que permitem que os atores se exprimam e se desenvolvam.

Como a etnometodologia, essa abordagem dá ênfase às capacidades reflexivas dos atores humanos ou às capacidades para compreender (e até mesmo para controlar) o que fazem no fluxo continuo da vida social. Entretanto, além disso, essa abordagem introduz uma diferenciação significativa em relação às modalidades de realização dessas capacidades: embora, de fato, a reflexividade possa manifestar-se no nivel verbal (enquanto consciência discursiva), ela opera de forma mais fundamental no nivel da consciência práti$c a$, "que é tudo aquilo que os atores conhecem de modo tácito, tudo que sabem fazer na vida social, sem que por isso possam exprimi-1o diretamente de modo discursivo" (Giddens, 1987: 33).

O que essa abordagem, combinada com a nossa, pode indicarnos sobre a questão da integração social e do desenvolvimento da cidadania? Essencialmente, que o trabalho formativo por nós apontado anteriormente deve basear-se na consciência prática dos atores e ter por objetivo desenvolver sua consciência ou competência discursiva, que é também uma competência reflexiva e criativa.

Entretanto, não se trata aqui de cairmos em uma visão "verbalista", que nos poderia levar a pensar que o desenvolvimento das capacidades de linguagem é suficiente, em si mesmo, para o desenvolvimento dessas capacidades sociais que são principalmente a integração e a cidadania. De nossa parte, temos desenvolvido trabalhos sobre esse tema específico, mas também desenvolvemos outros, principalmente com o grupo ALTER, do LAEL da PUC-SP, que focalizam a análise do agir não verbal e verbal de adultos em situação de trabalho (principalmente de ensino) e proponho, para finalizar, uma transposição dos procedimentos que adotamos, transposição essa que, evidentemente, traz alguns riscos, mas que poderia servir de base ou de exemplo para abordar os problemas referentes à cidadania e à inserção social. 
A meu ver, a formação voltada para os valores sociais deveria, primeiramente, partir do exame de situações concretas em que há problemas de integração e de cidadania, efetuando, junto com os alunos, uma análise das ações efetivas no quadro das quais se manifestam esses problemas. Essa análise das ações efetivas deveria permitir a coleta de elementos de conhecimento ou de consciência prática que os alunos já têm e, a seguir, um trabalho sobre essa consciência prática em duas direções.

A primeira teria por objetivo detectar as características das ações: suas propriedades materiais, os valores e as normas sociais que parecem determiná-las, e os aspectos constitutivos da responsabilidade (motivos e intenções) que são atribuídos aos agentes (pelos outros) ou que os próprios agentes assumem. Nesse nivel, os métodos de análise das ações que temos desenvolvido poderiam ser explorados, mas essencialmente como apoios metodológicos para os alunos: de qualquer modo, eles nos dariam "um aumento de zoom" sobre as propriedades das ações (como na fotografia) e alguma conceitualização dessas propriedades.

A segunda direção a ser tomada para um trabalho sobre a consciência prática consistiria em fazer os alunos produzirem, em contextos variados de ação e, conseqüentemente, em gêneros diferentes, textos que tenham a ver com essas problemáticas. De fato, esse trabalho visaria a desenvolver a competência discursiva dos alunos em relação a esses temas. Além do fato de que isso contribuiria para o desenvolvimento de sua maestria no uso da linguagem, na perspectiva que abordamos nesta conferência, ao mesmo tempo, esse trabalho permitiria explorar praticamente (verbalmente) as diversas facetas e as diversas concepções da integração ou da cidadania. A idéia geral é a de que, em vez de tentar levar os alunos a uma maestria dos modelos sociais vigentes em relação a essas problemáticas, que, no estado atual de nossas sociedades freqüentemente são pouco criveis ou pouco atrativos, é necessário contribuir para o desenvolvimento de suas capacidades reflexivas 
Rev. ANPOLL, n 19, p. 231-256, jul./dez. 2005.

sobre esses temas: guiá-los em suas reflexões, refletindo com eles sobre as coerções e sobre os pré-construtos sociais, que é indispensável considerar, mas deixando sempre espaços possiveis para as reformulações e para a criatividade dos alunos sobre esses temas, que são condições sine qua non para que eles se coloquem como atores efetivos da reconstrução e da melhoria desses processos e desses valores.

\section{BIBLIOGRAFIA}

ADAM, J.-M. (1990). Eléments de linguistique textuelle, Liège: Mardaga.

Bakнtine, M. (1984). Esthétique de la création verbale, Paris: Gallimard [Edição original: 1979. Reúne textos de arquivo escritos a partir da década de 1920.].

Bourdieu, P. (1980). Le sens pratique, Paris, Minuit.

Bronckart, J.-P. (1997). Activité langagière, textes et discours. Pour un interactionisme socio-discursif. Paris: Delachaux et Niestlé. [Tradução para o português de Anna Rachel Machado, EDUC:São Paulo, 1999].

Bronckart, J.-P. \& Stroumza, K. (2002). Les types de discours comme traces cristallisées de l'action du langage. In E. Roulet \& M. Burger (ed.), Les analyses de discours au défi d'un dialogue romanesque, Nancy, PUN: 213-263.

Bronckart, J.-P.; Bain; D.; Schneuwly, B.; Davaud, C. \& Pasguier, A. (1985). Le fonctionnement des discours. Un modèle psychologique et une méthode d'analyse. Paris: Delachaux \& Niestlé.

Coseriu, E. (2001). L'homme et son langage, Louvain: Peeters.

Dilthey, W. (1992). Introduction aux sciences de l'esprit. In. Dilthey - OEuvres

1, Paris, Editions du Cerf: 141-361 [Edição original: 1883].

Durkheim, E. (1963). Les règles de la méthode sociologique, Paris, P.U.F. [Edição original: 1894-1895].

Garfinkel, H. (1967). Studies in ethnomethodology, Engelwood Cliffs, PrenticeHall.

Giddens, A. (1987). La constitution de la société, Paris, P.U.F. [Edition originale: 1984].

Goffman, E. (1973). La mise en scène de la vie quotidienne. 1 La présentation de soi, Paris: Minuit [Edição original: 1956]. 
Conferência - Jean-Paul Bronckart

Grize, J.-B. (1984). Sémiologie du raisonnement, Berne: Peter Lang.

Habermas, J. (1987). Théorie de l'agir communicationnel, tome 1: Rationalité de l'agir et rationalisation de la société, Paris: Fayard.

Leontiev, A.N. (1979). The Problem of Activity in Psychology. In J.V. Wertsch (ed.), The Concept of Activity in Soviet Psychology, New-York: Sharpe: 37-71.

MeAd, G.H. (1934). Mind, self and society from the standpoint of a social behaviorist, Chicago: University of Chicago Press.

Ricœur, P. (1983). Temps et récit, t.1, Paris: Seuil.

ROULET et al. (1985). L'articulation du discours en français contemporain, Berne, Peter Lang.

Simmel, G. (1981). Sociologie et épistémologie, Paris: P.U.F. [Coletânea de textos de 1884 a 1918].

Touraine, A. (1973). Production de la société, Paris, Seuil.

Tradução e Apresentação: Anna Rachel Machado* Revisão: Adail Sobral ${ }^{*}$

- Pontifícia Universidade Católica de São Paulo - PUC-SP. 